\title{
Comparative Root and Stem Anatomy of Four Rare Onobrychis Mill. (Fabaceae) Taxa Endemic in Turkey
}

\author{
Mehmet TEKIN ${ }^{1 *}$, Gülden YILMAZ ${ }^{2}$

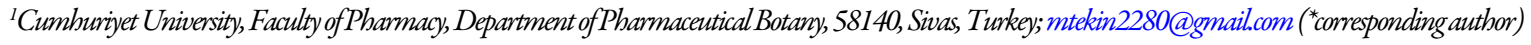 \\ ${ }^{2}$ Trakya University, Faculty of Science, Department of Biology, Balkan Campus, 22030, Edime, Turkey; guldenyilmaz2009@yahoo.com
}

\begin{abstract}
Four endemic taxa of Onobrychis Mill. genus, some of them being classified in the endangered threat category, were investigated for root and stem anatomy. Onobrychis quadrijuga, O. argyrea subsp. argyrea, O. tournefortii and $O$. albiflora were studied in regard to specific anatomy for the first time within the hereby study. Anatomical characters as the size and shape of the periderm, cortex, cambium cells in root and epidermis, collenchyma, cortex, cambium and pith cells in stem belonging to these four Onobrychis taxa were determined in detail. Based on the roots and stems measurements and analysis, specific anatomical differences between species were revealed.
\end{abstract}

Keywords: anatomy, endemic, Onobrychis, root, stem

\section{Introduction}

Fabaceae, represented by 750 genera and more than 18,000 species, is one of the largest dicot families, having species of profound economic importance (ILDIS, 2001). Onobrychis Mill., in the family Fabaceae, subfamily Faboideae, tribe Hedysareae DC. (Chase and Reveal, 2009) comprises 342 perennial and annual species. This genus is distributed throughout Northern temperate regions, Eastern Mediterranean region and Southwest Asia (Hedge, 1970; Hejazi et al., 2010). The diversity and concentration of these species are high in the region around Anatolia-Iran-Caucasia. There are 23 species of Onobrychis listed in The Flora Europaea (Tutin et al., 2001), whereas the main centre of diversity extended from Central Asia to Iran, were the number of species is increased to 56 species, 27 of which being endemic (ILDIS, 2005). In Turkey, the genera Onobrychis is represented by 55 species under five different sections and 28 of them are endemic (Hedge, 1970; Davis et al., 1988; Duman and Vural, 1990; Aktoklu, 2001; Y1ldırıml, 2004).

The species of Onobrychis (sainfoin) are economically important plants that are grown in order to produce highprotein fodder for animals. As these species can fix atmospheric nitrogen they are important for farm animal nourishment and soil fertility. Also, they have a great potential for pasture and meadow improvement, land conservation and rehabilitation, besides being important genetic sources for breeding (Cavallarin et al., 2005; Parlak and Parlak, 2008). Onobrychis play an important role in the soil environment by increasing the nutritive value of drought-resistant pasture (Abou-El-Enain, 2002).

There are several studies about palynology, taxonomy, karyology and cytotaxonomy of some Onobrychis taxa in the literature. The pollen morphology was used as the most important microscopic character in the taxonomy of Onobrychoidei (Pinar et al., 2009). A cytotaxonomic study of some Onobrychis (Fabaceae) species and populations in Iran determined the karyology of 20 taxa (45 populations) of the genus Onobrychis from different geographic origins (Hejazi et al., 2010). Ovule ontogenesis and megagametophyte development in Onobrychis schahuensis Bornm. (Fabaceae) were also studied (Chehregani and Tanaomi, 2010). Genetic relationships of the genera Onobrychis, Hedysarum, and Sartoria using seed storage proteins were determined (Arslan and Ertugrul, 2010). The pollen size and morphology of 20 Onobrychis taxa from Turkey were studied using both light and scanning electron microscopy (Avcr et al., 2013). Seed and germination characteristics of wild Onobrychis taxa in Turkey were determined (Avc1 and Kaya, 2013). Even so, based on the authors' bibliographical observations, the anatomical characteristics of Onobrychis were not studied well enough. There was a study including quantitative and qualitative characters of peduncle anatomy on 20 species of Onobrychis Miller sect. Heliobrychis Bunge from Iran by light microscopy (Karamian et al., 2012). Nodal anatomy of Onobrychis grandis (Fabaceae) and anatomy of Onobrychis cornuta (L.) Desv. sprout were determined (Zhogoleva, 1976, 1980).

However, there are no studies about root and stem anatomy of Onobrychis taxa in Turkey. Therefore, the aim of the current study was to determine the anatomy of root and stem of endemic taxa Onobrychis quadrijuga, $O$. argyrea subsp. argyrea, $O$. tournefortii and $O$. albiflora. Endemic species are both globally and locally important.

Conserving areas of high endemism might give a chance to further study the ecological, life history and physiological factors influencing endemics, while simultaneously protecting areas of 
Table 1. Natural habitat of investigated specimens of Onobrychis taxa

\begin{tabular}{|c|c|}
\hline Taxon & Locality, Collector, Collector number, Date \\
\hline O. quadrijuga & $\begin{array}{l}\text { B6 Sivas: Kangal-Gürün, } 8 \text { km; } 1,530 \text { m, N } 39^{\circ} 07^{\prime} \\
52,2^{\prime} \text { E } 37^{\circ} 14^{\prime} 33,4^{\prime \prime} \\
\text { M. Tekin 1250, 21.06.2012; ibid. M. Tekin 1284, } \\
\text { 30.06.2012 }\end{array}$ \\
\hline $\begin{array}{l}O \text {. argyrea subsp. } \\
\text { argyrea }\end{array}$ & $\begin{array}{l}\text { B6 Sivas: Ulaş, Ziyarettepe; } 1,406 \mathrm{~m}, \mathrm{~N} 39^{\circ} 33^{\prime} 08,9^{\prime \prime} \\
\text { E } 37^{\circ} 01^{\prime} 12,1^{\prime \prime} \\
\text { M. Tekin } 1287,30.06 .2012\end{array}$ \\
\hline O. tournefortii & $\begin{array}{l}\text { B6 Sivas: Sivas to Hafik, Emre village; } 1,317 \mathrm{~m}, \mathrm{~N} 39^{\circ} \\
49^{\prime} 37,5^{\prime \prime} \text { E } 37^{\circ} 17^{\prime} 05,1^{\prime \prime} \\
\text { M. Tekin } 1290,08.07 .2012\end{array}$ \\
\hline O. albiflora & $\begin{array}{l}\text { B6 Sivas: Sincan to Kangal, } 5 \mathrm{~km} ; 1,220 \mathrm{~m}, \mathrm{~N} 39^{\circ} 28^{\prime} \\
01,9^{\prime \prime} \text { E } 37^{\circ} 50^{\prime} 34,5^{\prime \prime} \\
\text { M. Tekin } 1291,08.07 .2012\end{array}$ \\
\hline
\end{tabular}
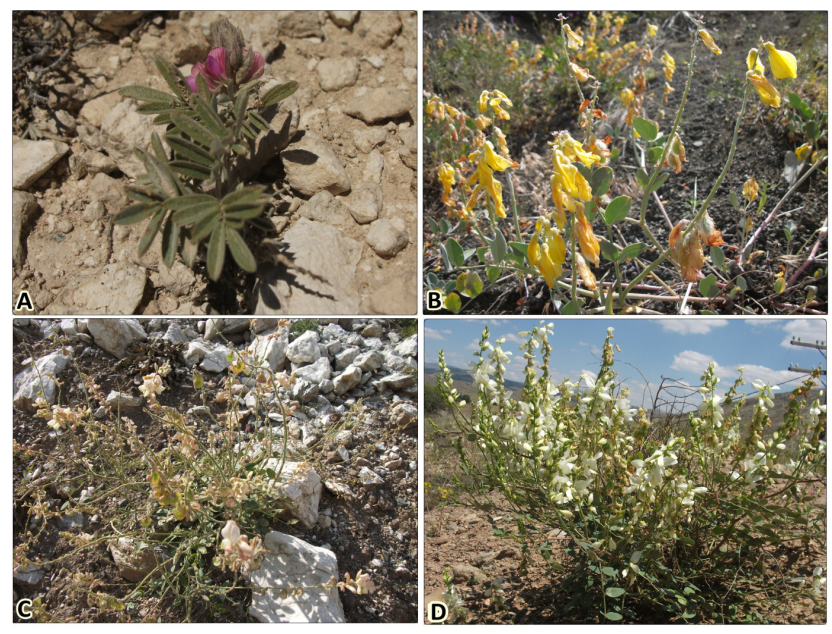

Fig. 1. General view of examined Onobrychis taxa in natural habitat: A) $O$. quadrijuga; B) O. argyrea subsp. argyrea; C) O. tournefortii; D) $O$. albiflora

variable habitat. Anatolia (Turkey) with its adjacent lowland environment can be considered in reference to the patterns and processes that characterize plant diversity, evolution and distribution (Fahn, 1990; Hassan and Heneidak, 2006; Mehrabian et al., 2007). Also, the morphological and anatomical studies on taxa are very important because some of them are threatened or under extinction. According to Red Data Book of Turkish Plants, treat category of $O$. albiflora is critically endangered (CR), O. quadrijuga is endangered (EN), while $O$. argyrea subsp. argyrea and $O$. tournefortii have the same threat category which is lower risk/conservation dependent $(\mathrm{LR} / \mathrm{cd})$ (Ekim et al., 2000).

\section{Materials and Methods}

The specimens used in this study were collected from natural habitats in Sivas province (Turkey). Localities and photos in natural habitat of investigated specimens of Onobrychis taxa were given in Table 1 and Fig. 1 respectively. Some specimens were prepared as herbarium materials and deposited in Cumhuriyet University Herbarium (CUFH). For anatomical studies, the root and stem of the some specimens were fixed and conserved in $70 \%$ ethyl alcohol. Hand sections were made with a razor blade and sections were stained with Alcian blue (Sigma) for pectic substances, and with Safranine O (Sigma) for lignin in the ratio of $3 / 2(\mathrm{AB} / \mathrm{SO})$. They were left in dye about 5 minutes for staining. The stained sections were mounted in glycerin-gelatine to obtain permanent preparations (Jensen, 1962). Sections were examined using an Olympus light microscope BX51. Photographs were captured using a digital camera (Olympus DP70) connected with the light microscope.

\section{Results and Discussion}

In this study, four Onobrychis taxa, endemic in Turkey, were studied for anatomical properties. General views with habitats of all examined taxa are given in Fig. 1.

Root and stem anatomy of Onobrychis quadrijuga, $O$. argyrea subsp. argyrea, $O$. tournefortii and $O$. albiflora were determined for the first time within this study. Anatomical characters, which were selected and quantified here, included the size and shape of the periderm, cortex, cambium cells in root and shape of epidermal cells, the number of collenchyma layers, the number of parenchyma layers in cortex, the shape of parenchymatous cells in pith and the secretory material in the cavities of stem in cross sections.

The order of listing the species in text, tables and photos was determined according to their evolutionary stage of development.

\section{Root anatomy}

Periderm cells were 8-14 layered on the outer surface of the root in O. quadrijuga, 3-8 layered in O. argyrea subsp. argyrea, 4-7 layered in 0 . tournefortii and 7-12 layered in $O$. albiflora. There were individually or as a bundle of sclerenchymatic fibre cells in periderm and among periderm with cortex in $O$. quadrijuga, while there was not sclerenchymatous tissue in periderm in all the others species examined hereby (Fig. 2; Table 2).

Parenchyma cells were generally irregular, occasionally rectangular oval shaped in $O$. quadrijuga, generally irregular or occasionally depressed rectangular and depressed oval shaped in $O$. argyrea subsp. argyrea and $O$. tournefortii, irregular shaped in O. albiflora (Fig. 2; Table 2). There were individually or as a bundle of sclerenchymatic fibre cells in cortex, secondary phloem and secondary xylem in all examined species.

O. quadrijuga had the largest secondary phloem among the Onobrychis species studied in this study, while the amount of sclerenchymatic fibre cells in $O$. albiflora was more than in the rest of the examined species (Fig. 2; Table 2).

Cambium was generally distinguishable, but occasionally indistinguishable in $O$. quadrijuga, distinguishable in $O$. argyrea subsp. argyrea, in $O$. tournefortii and in $O$. albiflora. Secondary pith rays consisted of 2-4 layered parenchymatous cells, which were heterogenous in $O$. quadrijuga. In secondary xylem, diameter of trachea was $10-63 \mu \mathrm{m}$ in $O$. quadrijuga, $15-100 \mu \mathrm{m}$ in $O$. argyrea subsp. argyrea, 17-95 $\mu \mathrm{m}$ in $O$. tournefortii, $15-88 \mu \mathrm{m}$ in $O$. albiflora. In the center of the root there were many sclerenchymatic fibre cells in $O$. albiflora, distinctive than in the other taxa examined (Fig. 2; Table 2).

\section{Stem anatomy}

When cross sections of stems were examined it was noted that the epidermis consisted of square, rectangular or rectangular oval cells in $O$. quadrijuga, square or rectangular, occasionally rectangular oval cells in $O$. argyrea subsp. argyrea, square or rectangular cells in $O$. tournefortii, generally depressed 
310

Table 2. The length and width measurements of cells $(\mu \mathrm{m})$ and cell layer number in root and stem of examined Onobrychis taxa

\begin{tabular}{|c|c|c|c|c|c|c|c|c|c|c|}
\hline & & & \multicolumn{2}{|c|}{ O.quadrijuga } & \multicolumn{2}{|c|}{$O$. argyrea subsp. argyrea } & \multicolumn{2}{|c|}{ O. tournefortii } & \multicolumn{2}{|c|}{ O. albiflora } \\
\hline & & & $\min$ & $\max$ & $\min$ & $\max$ & $\min$ & $\max$ & $\min$ & $\max$ \\
\hline \multirow{11}{*}{$\begin{array}{l}\ddot{\circ} \\
\stackrel{8}{2}\end{array}$} & Periderm & Length & 17 & 43 & 17 & 45 & 12 & 93 & 12 & 28 \\
\hline & cell & Width & 3 & 10 & 4 & 13 & 5 & 18 & 5 & 15 \\
\hline & Periderm cell layer & & 8 & 14 & 3 & 8 & 4 & 7 & 7 & 12 \\
\hline & & Length & 10 & 75 & 17 & 73 & 17 & 140 & 17 & 73 \\
\hline & Cortex cell & Width & 7 & 38 & 10 & 43 & 7 & 108 & 12 & 40 \\
\hline & Cortex cell layer & & 6 & 9 & 7 & 10 & 10 & 18 & 8 & 13 \\
\hline & & Length & 10 & 25 & 10 & 15 & 10 & 23 & 12 & 25 \\
\hline & Cambium cell & Width & 2 & 6 & 3 & 6 & 2 & 8 & 2 & 7 \\
\hline & Cambium cell layer & & 2 & 3 & 2 & 6 & 3 & 7 & 2 & 6 \\
\hline & Seconder pith ray layer & & 2 & 4 & 3 & 7 & 2 & 8 & 3 & 6 \\
\hline & Diameter of trachea & & 10 & 63 & 15 & 100 & 17 & 95 & 15 & 88 \\
\hline \multirow{10}{*}{ 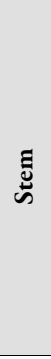 } & \multirow{2}{*}{ Epidermis cell } & Length & 5 & 15 & 7 & 20 & 4 & 25 & 7 & 43 \\
\hline & & Width & 5 & 13 & 4 & 10 & 4 & 20 & 5 & 10 \\
\hline & \multirow{2}{*}{ Cortex cell } & Length & 12 & 50 & 10 & 40 & 10 & 50 & 10 & 53 \\
\hline & & Width & 5 & 25 & 7 & 30 & 7 & 43 & 7 & 28 \\
\hline & Cortex cell layer & & 6 & 10 & 8 & 11 & 8 & 11 & 8 & 12 \\
\hline & \multirow{2}{*}{ Cambium cell } & Length & 7 & 15 & 10 & 23 & 10 & 18 & 12 & 18 \\
\hline & & Width & 2 & 5 & 2 & 8 & 2 & 8 & 3 & 7 \\
\hline & Cambium cell layer & & 3 & 5 & 1 & 3 & 2 & 4 & 1 & 3 \\
\hline & \multirow{2}{*}{ Pithcell } & Length & 50 & 160 & 35 & 200 & 20 & 120 & 17 & 125 \\
\hline & & Width & 40 & 130 & 28 & 175 & 20 & 105 & 15 & 115 \\
\hline
\end{tabular}

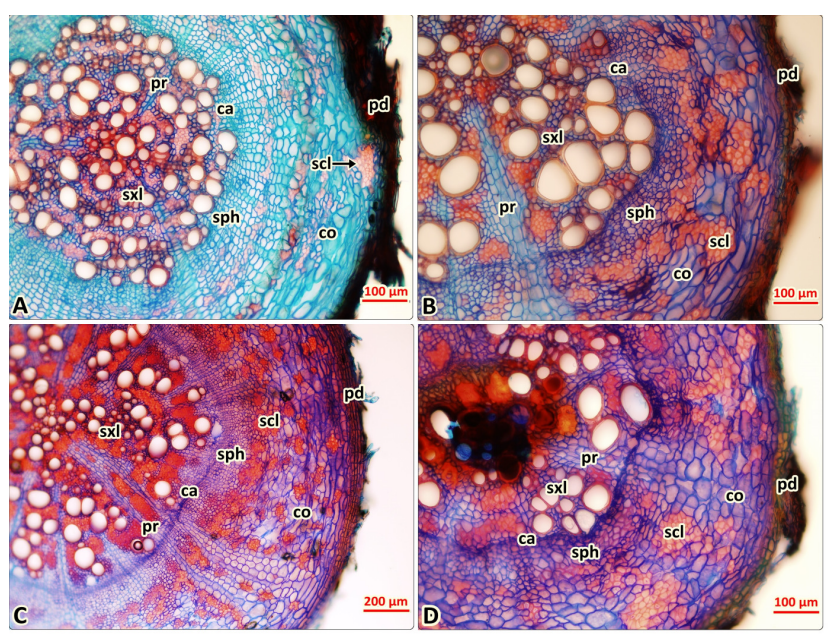

Fig. 2. Cross sections of roots of examined Onobrychis taxa: A) $O$. quadrijuga; B) O. argyrea subsp. argyrea; C) O. tournefortii; D) $O$. albiflora; ca: cambium; co: cortex, pd: periderma; pr: pith ray; scl: sclerenchyma; sph: secondary phloem; sxl: secondary xylem

rectangular or occasionally square cells in O. albiflora. There were single celled eglandular hairs on the epidermis in all examined species except $O$. albiflora. Underneath the epidermis there was collenchyma with single layered cells, while collenchyma in cortex was multilayered, among epidermis and phloem schlerenchyma in all of the taxa. In addition to this, phloem sclerenchyma was larger in $O$. tournefortii and $O$. albiflora than in the other species (Fig. 3; Table 2).

Cortex consisted of parenchyma cells in all of the species. Cells of cortex were oval, rectangular oval and occasionally irregular shaped in $O$. quadrijuga, oval and circular shaped in all of the other species in the study. There were sclerenchymatic fibre bundle in floem and more intensely in xylem in O. quadrijuga (Fig. 3; Table 2).

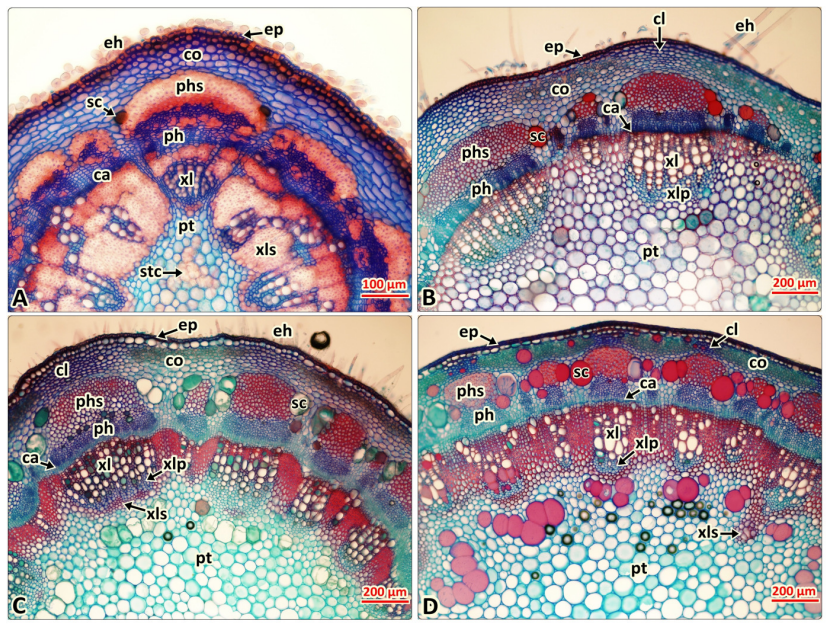

Fig. 3. Cross sections of stems of examined Onobrychis taxa: A) $O$. quadrijuga; B) O. argyrea subsp. argyrea; C) O. tournefortii; D) $O$. albiflora; ep: epiderma; eh: eglandular hair; ca: cambium; cl: collenchyma; co: cortex parenchyma; pt: pith parencyma; ph: phloem; phs: phloem sclerenchyma; sc: secretory cell; stc: stone cell; xl: xylem; xlp: xylem parenchyma; xls: xylem sclerenchyma

Cambium was distinguishable in $O$. quadrijuga. There were pith rays which consisted of 2-5 layers, between pith region and cortex in $O$. quadrijuga. There were secretory storage cells, larger than the other cells in cortex, especially close to the phloem sclerenchyma and in pith region in all of the examined species except $O$. quadrijuga. Pith cells were parenchymatous, oval or circular shaped in all species. In pith region, as a distinct feature among studied taxa, some parenchymatous cells turned into stone cells in O. quadrijuga.

There is no anatomical study on Onobrychis taxa in Turkey. There was a study about morphological, anatomical and palynological characters for $O$. cornuta (L.) Desv., $O$. arnacantha Boiss., $O$. verae Sirj. var. verae, $O$. verae Sirj. var. 
rechingeri Sirj., O. ptycophylla (Del.) DC., O. amoena subsp. amoena Popov \& Vved, O. amoena subsp. meshhedensis Sirj. \& Rech.f, O. chorassanica Bunge ex Boiss. growing in Northeast Iran (Amirabadizadeh et al., 2014). Morphological study, shape, size and color of vegetative organs and legumes were assessed, while for the anatomical study, cross sections of mature fresh or dried stems, leaflets and petioles were prepared and stained (Amirabadizadeh et al., 2014). Schweingruber et al. (2011) reported that in the Onobrychis stems, vessels and fibers were arranged in tangential layers and were surrounded by paratracheal and marginal parenchyma. The large rays were not lignified.

The distribution of axial parenchyma cells can be apotracheal. In te current study cortex was made of parenchyma cells in all species as 6-10 layered in O. quadrijuga, 8-11 layered in $O$. argyrea subsp. argyrea and in $O$. tourneforti and 8-12 layered in O. albiflora. The results are similar with the findings of the stem anatomy study of some Onobrychis species belonging Northeast Iran (Amirabadizadeh et al., 2014): 9-12 layered in O. cornuta, 4 9 layered in $O$. arnacantha, 5-8 layered in $O$. verae var. verae, 5-7 layered in $O$. verae var. rechingeri, $4-9$ layered in $O$. ptycophylla, 37 layered in $O$. amoena subsp. amoena, 5-9 layered in $O$. amoena subsp. meshhedensis, 6-10 layered in O. chorassanica.

Other researchers studied the peduncle anatomy of four groups of Onobrychis taxa in Iran (Karamian et al, 2012). It was noted the existence of some cavities within cortex parenchyma and also around pericyclic fibres. In the current study, cavities were also observed in cross sections of stem, while no cavity was seen in root sections. These cavities were filled with secretory material from the secretory cells (sc), stained red with safranine dye (Fig. 3).

\section{Conclusions}

In this study, anatomical properties of roots and stems of $O$. quadrijuga, $O$. argyrea subsp. argyrea, $O$. tournefortii and O. albiflora, some of them being classified in the endangered threat category, were determined in detail for the first time. When root sections were compared within each other some differences were noted: there was not sclerenchymatous tissue in periderm in the examined species, except $O$. quadrijuga; $O$. quadrijuga had the largest secondary phloem among the Onobrychis species in the study; the amount of sclerenchymatic fibre cells in O. albiflora was more than in the other species. When stem sections were compared with each other, the differences determined were as follows: there were single-celled eglandular hairs on the epidermis in all examined species except $O$. albiflora; phloem sclerenchyma was larger in $O$. tournefortii and O. albiflora than in the other species; in pith region, as distinct from other three taxa, some parenchymatous cells turned into stone cells in $O$. quadrijuga.

\section{References}

Abou-El-Enain MAGED (2002). Chromosomal criteria and their phylogenetic implications in the genus Onobrychis Mill. Sect. Lophobrychis (Leguminosae), with special reference to Egyptian species. Botanical Journal of the Linnean Society 139:409-414.

Aktoklu E (2001). Two new varieties and a new record in Onobrychis from Turkey. Turkish Journal of Botany 25:359-363.
Amirabadizadeh H, Jafari A, Mahmoodzadeh H (2014). Comparative morphology, anatomy and palynological studies of perennial species of Onobrychis (Fabaceae) in northeast Iran. Nordic Journal of Botany 33(2):159-169.

Arslan E, Ertugrul K (2010). Genetic relationships of the genera Onobrychis, Hedysarum, and Sartoria using seed storage proteins. Turkish Journal of Botany 34:67-73.

Avc1 S, Kaya MD (2013). Seed and germination characteristics of wild Onobrychis taxa in Turkey. Turkish Journal of Botany 37:555-560.

Avcı S, Sancak C, Can A, Acar A, Punar NM (2013). Pollen morphology of the genus Onobrychis (Fabaceae) in Turkey. Turkish Journal of Botany 37:669-681.

Cavallarin L, Antoniazzi S, Borreani G, Tabacco E (2005). Effects of wilting and mechanical conditioning on proteolysis in sainfoin (Onobrychis viciifolia Scop.) wilted herbage and silage. Journal of the Science of Food and Agriculture 85:831-838.

Chase MW, Reveal WJ (2009). A phylogenetic classification of the land plants to accompany APG III. Botanical Journal of the Linnean Society 161:122-127.

Chehregani A, Tanaomi N (2010). Ovule ontogenesis and megagametophyte development in Onobrychis schabuensis Bornm. (Fabaceae). Turkish Journal of Botany 34:241-248.

Davis PH, Mill RR, Tan K (1988). Flora of Turkey and the East Aegean Islands (Supplement), Vol 10. Edinburgh University Press.

Duman H, Vural M (1990). New taxa from south Anatolia I. Turkish Journal of Botany 14:45-48.

Ekim T, Koyuncu M, Vural M, Duman H, Aytac Z. Adıguzel N (2000). Red Data Book of Turkish Plants. Ankara: Turkish Association for the Conservation of Nature.

Fahn A (1990). Plant Anatomy. 4th ed. New York: Pergamon Press.

Hassan AE, Heneidak S (2006). Stem anatomy and nodal vasculature of some Egyptian Vicia species (Fabaceae). Pakistan Journal of Biological Science 9:2556-2563.

Hedge IC (1970). Onobrychis. Adans. In: Davis PH (Ed). Flora of Turkey and the East Aegean Islands. Edinburgh University Press.

Hejazi H, Mohsen S, Nasab MZ (2010). Cytotaxonomy of some Onobrychis (Fabaceae) species and populations in Iran. Caryologia 63(1):18-31.

International Legume Database \& Information Service (ILDIS) (2001). Legumes of the World. UK:The University of Reading.

International Legume Database \& Information Service (ILDIS) (2005). Genus Onobrychis. Version 10.01, November 2005. Retrieved 2009 January 26 from http://www.ildis.org/database/.

Jensen WA (1962). Botanical Histochemistry. San Francisco: WH Freeman and Co.

Karamian R, Behjou AM, Ranjbar M (2012). Anatomical findings of Onobrychis sect. Heliobrychis (Fabaceae) in Iran and their taxonomic implications. Turkish Journal of Botany 36:27-37.

Mehrabian AR, Zarre SH, Azizian D, Podlech D (2007). Petiole anatomy in Astragalus Sect. Incani DC. (Fabaceae) in Iran. Iran Journal Botany 13:138-145.

Parlak AÖ, Parlak M (2008). Effect of salinity in irrigation water on some plant development parameters of sainfoin (Onobrychis 
viciifolia Scop.) and soil salinity. Tarim Bilimleri Dergisi-Journal of Agricultural Sciences 14(4):320-325.

Pınar NM, Ekici M, Aytac Z, Akan H, Ceter T, Alan Ş (2009). Pollen morphology of Astragalus L. sect. Onobrychoidei DC. (Fabaceae) in Turkey. Turkish Journal of Botany 33:291-303.

Schweingruber FH, Börner A, Schulz ED (2011). Atlas of stem anatomy in herbs, shrubs and trees, $\mathrm{Vol}$ 1. Springer.

Tutin TG, Heywood VH, Burges NA, Valentine DH, Walters SM, Webb DA (2001). Flora Europaea. Cambridge University Press.
Yuldırımlı Ş (2004). A new species and subspecies of Onobrychis, $O$. cigdemae and $O$. cigdemae subsp. gorkemii (Fabaceae) from Şırnak, Turkey. Ot Sist. Bot. Derg 11:1-10.

Zhogoleva EP (1976). Anatomy of Onobrychis cornuta (L.) Desv. sprout. Izv Akad Nauk Tadzh SSR 2:25-32.

Zhogoleva EP (1980). Nodal anatomy of Onobrychis grandis (Fabaceae). Botanicheskii Zhurnal 65(11):1601-1604. 